\title{
IMPROVEMENT OF OPERABILITY OF DOUBLE-DISC COULTERS OF GRAIN SEEDERS WITH UHMWPE COATING ON SOILS OF VARIOUS MOISTURE
}

\author{
Ramil Iskenderov, Anatoly Lebedev, Pavel Lebedev, Anton Zaharin \\ Stavropol State Agrarian University, Russia \\ iskenderov_ramil@inbox.ru
}

\begin{abstract}
Sowing is carried out in certain agronomic terms, and up to $80 \%$ of grain seeders produced at present are equipped with double-disc coulters. Excessive stickiness of the soil causes sticking on the tools, and dried soil leads to disruption of the formation of the grooves, and increased wear of the tools. Each of these factors leads to disruption of the normal functioning of double-disc coulters of grain seeders and increases the traction resistance of the machine-tractor unit. To combat high adhesion of the soil to the metal, various coatings are used. The most widely used are polymeric materials, such as fluoroplastic and polyethylene. There is a good practice, both in the processing of working bodies of tillage equipment with liquid polymer compositions, and in the manufacture of individual or whole parts from plastic. Our analysis showed that most of the studies that develop soil-cultivating equipment with polymer coatings are devoted to sticking to the working organs of the soil, and little attention has been paid to the wear resistance of such equipment. Nevertheless, this problem exists, because with soil moisture up to $15 \%$, polymer work surfaces begin to wear out more intensively on small abrasive particles of the soil. Up to $50 \%$ of the energy of machine-tractor units is spent on friction on the soil of their working bodies. The use of coatings of ultra-high molecular weight (UHMWPE), which at low adhesion have high wear resistance, is preferable for the work of double-disc coulters on soils of different moisture. The experiments showed that UHMWPE has a higher relative wear resistance and a reduced coefficient of friction than fluoroplastic and, in some conditions, metal. The use of UHMWPE coating allows to increase the working time of double-disc coulters due to the possibility of sowing at an earlier time, when the soil moisture is in the range of $24-30 \%$, and to reduce the working time with increased abrasive wear when sowing in dry soil with a moisture content of less than $13-15 \%$.
\end{abstract}

Keywords: grain seeders, double-disc coulter, soil adhesion, wear resistance of working surfaces, application of UHMWPE.

\section{Introduction}

Studies on the interaction with the soil of various structural materials (bronze, copper, glass, ceramics, stainless steel, chrome, nickel and various polymers) have shown their effectiveness in eliminating sticking and reducing the friction coefficient, but insufficient wear resistance and high costs of application technology do not allow to use them widely. Scientists involved in the development of these technologies solve the problem of soil sticking, forgetting that there are regions around the world, where, due to dry seasons, crops are forced to be carried out in dry soil.

The most widely used polymers for modernization of tillage equipmentare - fluoroplastic and polyethylene. The existing positive practice of using polymeric materials, both when applying them in liquid form [1] and fixing in the form of overlays [2-4], does not provide enough data on the tribotechnical interaction of such surfaces with a soil layer of different moisture.

At the same time, to ensure operability and reduce the energy costs, when designing tillage and other equipment, ultra-high molecular weight polyethylene UHMWPE is used, which is up to 6.7 times more wear-resistant than fluoroplastic and retains all its positive properties. Despite this, this type of plastic has not yet been used for modernization of sowing grain aggregates and double-disc coulters [5-7].

Using polymer coatings on double-disc coulters of grain seeders should: prevent soil from sticking at high humidity, be wear-resistant when working in dry soil, not be damaged, experiencing increased loads, and not violate the required quality of sowing. To ensure operability in various soil moisture conditions, we propose to upgrade the double-disc coulter of the grain seeder with UHMWPE PE-1000 or the cheaper PE-500, which were designed to withstand the highest loads for a long period of use. The material has extremely high wear resistance, low friction coefficient and increased impact strength, which allows to replace metals with it, including: steel alloys, bronze and several others, as well as fluoroplastic. So, from the point of view of wear resistance, UHMWPE at its working temperatures and some abrasives is superior to Teflon and even carbon steel. The friction coefficient of UHMWPE (for steel) is about 0.1 . The impact coefficient is $170 \mathrm{~kJ} \cdot \mathrm{m}^{-2}$ (with a notch up to $80 \mathrm{~kJ} \cdot \mathrm{m}^{-2}$ ), working temperatures - from minus $260^{\circ} \mathrm{C}$ to plus $80^{\circ} \mathrm{C}$. It has very low water 
absorption for organic polymer compounds in the range of 0.01 to $0.05 \%$, which indicates an extremely low adhesion to any materials [8].

Having analyzed the methods of using polymers in soil cultivation, the main ones can be summarized in Table 1.

Table 1

Use of polymeric materials to improve the sowing process with double-disc coulters

\begin{tabular}{|c|c|c|c|}
\hline Type of disc coulters & Using for & Advantage & Disadvantage \\
\hline Standard paintwork & - & $\begin{array}{l}\text { Easy to operate and } \\
\text { repair }\end{array}$ & $\begin{array}{l}\text { Work in limited conditions } \\
\text { (physical ripeness of the soil, } \\
\text { i.e. humidity } W_{a}=13-24 \% \text { ) }\end{array}$ \\
\hline $\begin{array}{l}\text { Sprayed polymer } \\
\text { coating }\end{array}$ & $\begin{array}{l}\text { Anti-sticking } \\
\text { soil }\end{array}$ & $\begin{array}{l}\text { Increases reliability on } \\
\text { increased soil moisture }\end{array}$ & $\begin{array}{c}\text { Thin coating breaks and } \\
\text { wears out quickly }\end{array}$ \\
\hline $\begin{array}{l}\text { With polymer pads } \\
\text { mechanically fixed }\end{array}$ & \multirow{4}{*}{$\begin{array}{l}\text { Operability } \\
\text { under variable } \\
\text { soil moisture } \\
\text { conditions }\end{array}$} & \multirow{4}{*}{$\begin{array}{l}\text { Reliability in wet soil } \\
\text { and the ability to work } \\
\text { in dry wear soil }\end{array}$} & $\begin{array}{l}\text { Clogging of soil particles } \\
\text { between the pad and disc }\end{array}$ \\
\hline $\begin{array}{l}\text { With polymer pads } \\
\text { glued to the disc }\end{array}$ & & & $\begin{array}{l}\text { Ability to tear off the surface } \\
\text { during operation }\end{array}$ \\
\hline $\begin{array}{l}\text { Partially or fully made } \\
\text { from polymers }\end{array}$ & & & Fragility \\
\hline $\begin{array}{l}\text { Fastening by } \\
\text { combined methods } \\
\text { (mechanical and } \\
\text { adhesive) }\end{array}$ & & & More expensive technology \\
\hline
\end{tabular}

\section{Materials and methods}

To conduct experiments in an abrasive medium, we refitted the MTU-01 friction machine, equipped with a strain gauge with ZetLab software and allowing to record the friction moment in real time [9]. The test method of the MTU-01 friction machine is based on the rotational movement of the upper sample relative to the stationary lower sample; we made a holder element for pressing in the initial samples and a glass with a cover for the soil (Figure 1, a, b). Thus, the corresponding polymer or steel sample was placed in the insertion element, which was installed on the MTU-01 friction machine (Figure 1, c). and rotated in a glass filled with soil by $70-85 \%$. The soil sample with high wear properties was selected - medium loam chestnut soil with a moisture content of $W_{a}=5-25 \%$ with a content of physical clay (particles less than $0.1 \mathrm{~mm}$ ) 30-40\% in its composition.

a)

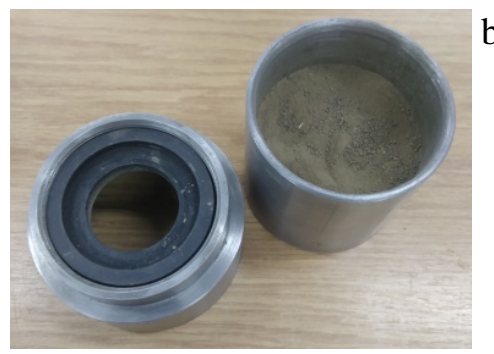

b)

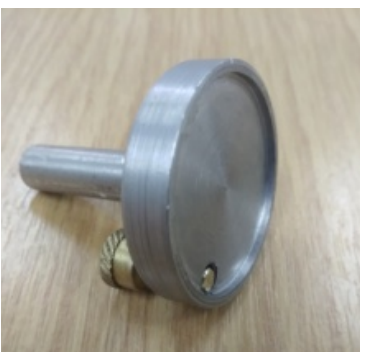

c)

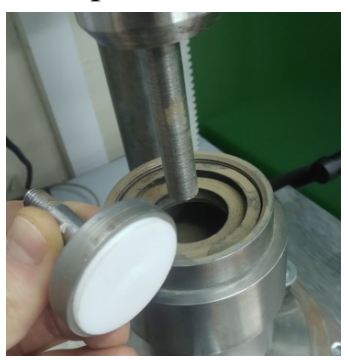

Fig. 1. Testing samples on an MTU-01 friction machine: $a$ - glass with a cover; $b$ - holder element for pressing in the initial samples; $\mathrm{c}$ - installation of a tribocouple

The strain gauge and software during testing allows to record the moment of friction in real time with a graphical display of its changes. The wear of the samples was recorded on a laboratory balance Acculab ALC-210d4 with an accuracy of up to $0.0001 \mathrm{~g}$.

In the field, standard and modernized coulters were compared by the amount of soil adhering to them with the soil moisture content $W_{a}=15-18 \%$ (medium loamy chernozem). The average amount of soil mass adhering to the wide-row double-disc coulters of the SZ-3.6 seeder was determined at the above moisture content and the speed of the sowing unit of $10 \mathrm{~km} \cdot \mathrm{h}^{-1}$. In addition, the optimum 
number of mechanical fastening plates was established in terms of saving resources on the conversion of coulter discs and in terms of reliable connections.

In the patent of the Russian Federation No. 190896 [10] we propose a double-disc coulter, shown in Figure 2, for sowing seeds, which consists of a lead 1 connected to the housing 2, two flat discs 3 mounted on it at an angle to each other with cutting edges with the possibility of rotation placed between them with a scraper 4 for cleaning the inner planes of the disk, a bell 5 for feeding seeds and hubs 6 protruding to the outside of the disks 3 , and a continuous axisymmetric protective pad 7 of a hydrophobic and wear-resistant material is installed on each flat disk from the outside with centering ribs around the hub 8 , worn on the hub 6 and fixed to the disc 9 with the clip heads countersunk on the inside, for a protective pad 7 and the discs 3 are arranged openings 10 and 11 respectively in the desired diameter and shape.

a)

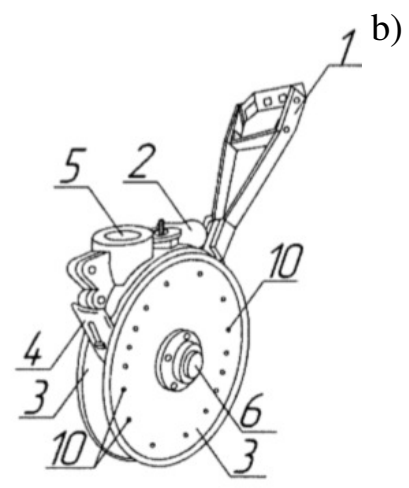

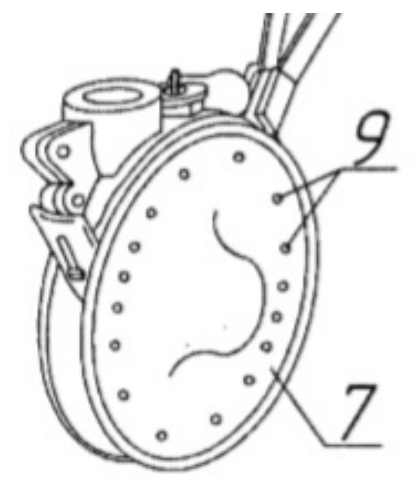

c)

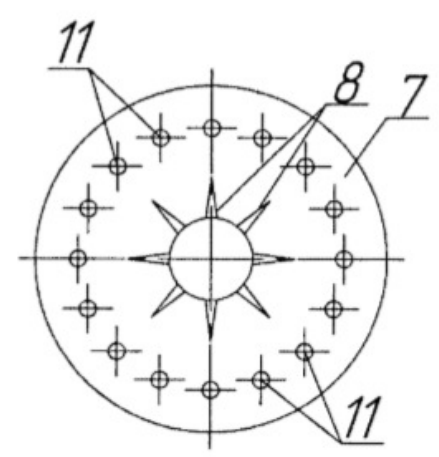

Fig. 2. Upgraded dual disc coulter layout: $\mathrm{a}$ - general view; $\mathrm{b}$ - polymer pad; c - pad fastening

The dimensions, thickness and other parameters of the lining should be calculated theoretically and then verified experimentally. Also, in practice, it is not always necessary to have removable surfaces; therefore, more complex structural clips can be replaced, for example, with rivets and additionally glued patch around the circumference. Guided by the known data, it is possible to present theoretical calculations and justify the number of mounts for UHMWPE lining.

Having conditionally accepted the first repair diameter $D_{l}=346 \mathrm{~mm}$, the minimum (last) $D_{l}=326 \mathrm{~mm}$, and the initial disk profile $D_{0}=350 \mathrm{~mm}$, we will depict them schematically in Figure 3 .

a)

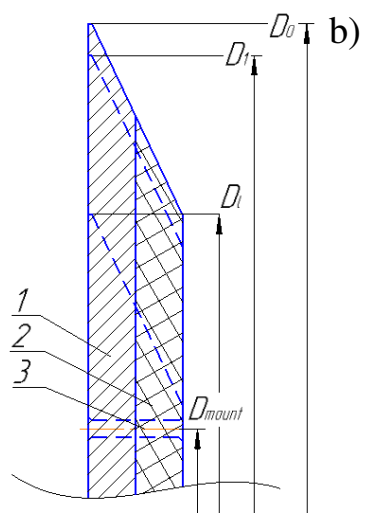

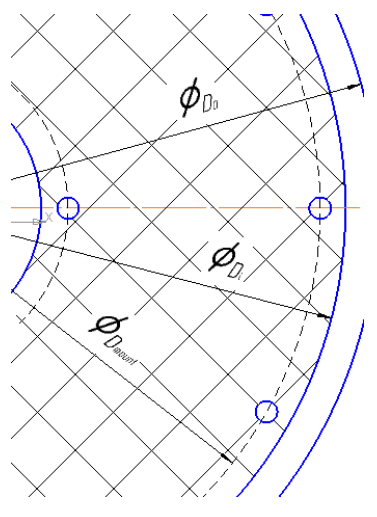

c)

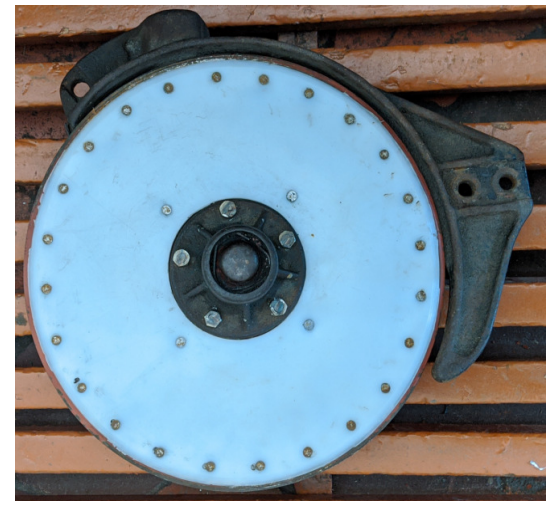

Fig. 3. Scheme of fragments of the front (a) and profile (b) parts of the upgraded disk with repair dimensions and its photo (c)

As shown in the diagram of Figure 3, mechanical fasteners 3 can be installed according to the diameter of the disk $D_{\text {mount }}$, which should be less than $D_{l}$, which, when wear-resistant, allows UHMWPE to operate the upgraded disk until it is completely rejected. The figure also shows that the upgraded disk has a greater thickness than the standard one and includes the width of the disk 1 and the polymer lining 2 . It will be important to determine the optimal number of rivets holding the UHMWPE pad in diameter $D_{\text {mount }}$ (Figure $3, \mathrm{c}$ ).

During the field tests, the amount of soil falling into the gap between the disk and the UHMWPE gasket (as an indicator of the reliability of fastening), with a different number of mechanical fasteners 
(rivets) around the circumference of the disk, was recorded. According to the experimental data, at least 22-25 pieces of mechanical fasteners are necessary to cover UHMWPE. In this case, there are no particles of soil falling into the gap, while the maximum amount of soil in the gap was in the range of 0.015-0.03 kg for 16-8 pcs mounts. For further tests we used opener discs with overlays of UHMWPE PE-500 with a thickness of $3 \mathrm{~mm}$ fixed 24 pcs rivets by $D_{\text {mount }}$.

Laboratory tests to check the traction resistance and soil sticking (blend of chernozems at $W_{a}=5$ $25 \%$ ) of the upgraded double-disk coulters compared to the standard ones were carried out at the Soil Canal laboratory bench installed in the training laboratory "Soil Processing Technique" of the Faculty of Agricultural Mechanization of FSBEI HE "Stavropol State Agrarian University". The operator, through the electric winch, drives the slide and the coulter prototype mounted on them. DACELL-UUK500 strain gauge readings - up to $500 \mathrm{~kg}$ are processed by the KYOWA EDX-100A station, which transmits the actual number of load indicators to the computer (Figure 4).

a)

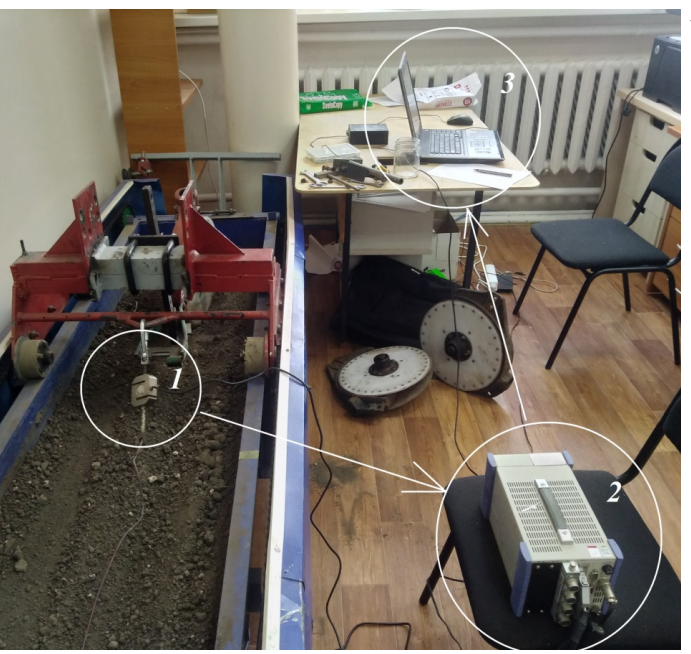

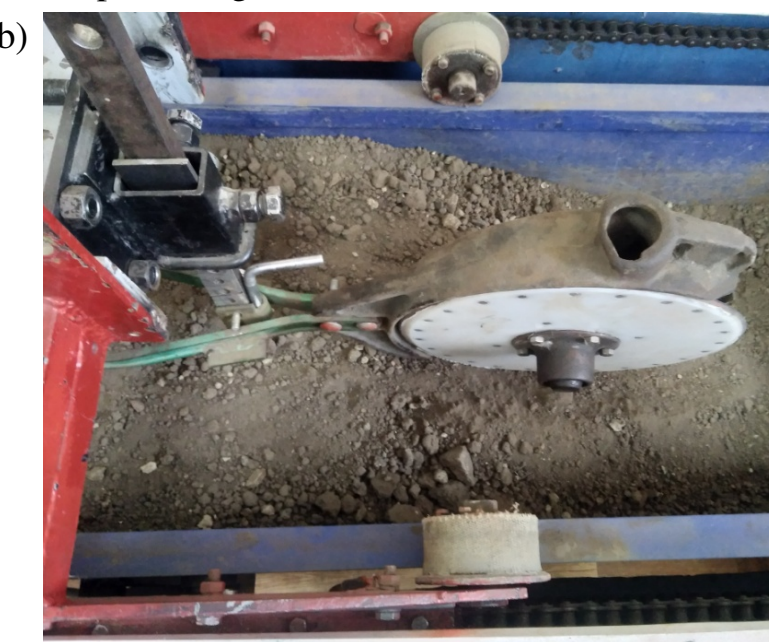

Fig. 4. Testing double disc coulters in the soil channel: $a$ - general view; $b$ - coulter mount

The amount of soil adhering to disk coulters during the laboratory and field tests was recorded by collecting adhering soil from the surface of the disks. After the coulter passed through the soil channel in both directions $(8 \mathrm{~m})$, the soil adhering to the discs was cleaned, collected in a special plastic container and weighed to the accuracy of $5 \mathrm{~g}$. During the field trials, after the opener passed about 1 $\mathrm{km}$, the adhered soil was collected in a similar way and weighed with an accuracy of $5 \mathrm{~g}$. The coulter speed during this test was at the level of $10 \mathrm{~km} \cdot \mathrm{h}^{-1}\left(v_{c}=2.7 \mathrm{~m} \cdot \mathrm{s}^{-1}\right)$.

\section{Results and discussion}

The test results in the environment of the abrasive on the installation of MTU-01 are presented in Table 2.

Test results of polymer samples on the installation of MTU-01

Table 2

$\left(W_{a}=5-25 \%\right.$, medium loam chestnut soil)

\begin{tabular}{|c|c|c|c|c|}
\hline \multirow{2}{*}{ Index } & \multicolumn{4}{|c|}{ Sample } \\
\cline { 2 - 5 } & 65G steel, 54 HRC & Fluoroplast-4 & UHMWPE PE-500 & UHMWPE PE-1000 \\
\hline $\begin{array}{c}\text { Friction } \\
\text { coefficients } \\
W_{a}=5-25 \%\end{array}$ & $0.43-0.79$ & $0.24-0.46$ & $0.18-0.42$ & $0.17-0.34$ \\
\hline $\begin{array}{c}\text { Relative wear } \\
\text { rate }\end{array}$ & 1 & 4.53 & 0.31 & 0.26 \\
\hline
\end{tabular}

As it can be seen from the table, ultra-high molecular weight polyethylenes (UHMWPE) turned out to be the most wear-resistant polymers, in which the relative wear rate is up to 18 times lower than that of fluoroplast- 4 and up to 4 times lower than that of steel. The friction coefficients $\mathrm{f}$ at soil moisture (medium loamy chestnut) from 5 to $25 \%$, respectively, amounted to $0.43-0.79$ for steel $65 \mathrm{G}$, 
0.24-0.46 for fluoroplast-4, for PE-500 UHMWPE - 0.18-0.42 and for UHMWPE PE-1000 - 0.170.34 , which is up to 2.5 times less than that of $65 \mathrm{G}$ steel with a hardness of $54 \mathrm{HRC}$. UHMWPE and also has the lowest coefficient of friction on the soil among the tested materials.

Based on the experimental data, in the field and laboratory conditions, graphs of the dependences of the mass of adhering to the wide-row double-disc coulters of the standard sample and to the surfaces upgraded from UHMWPE are constructed.

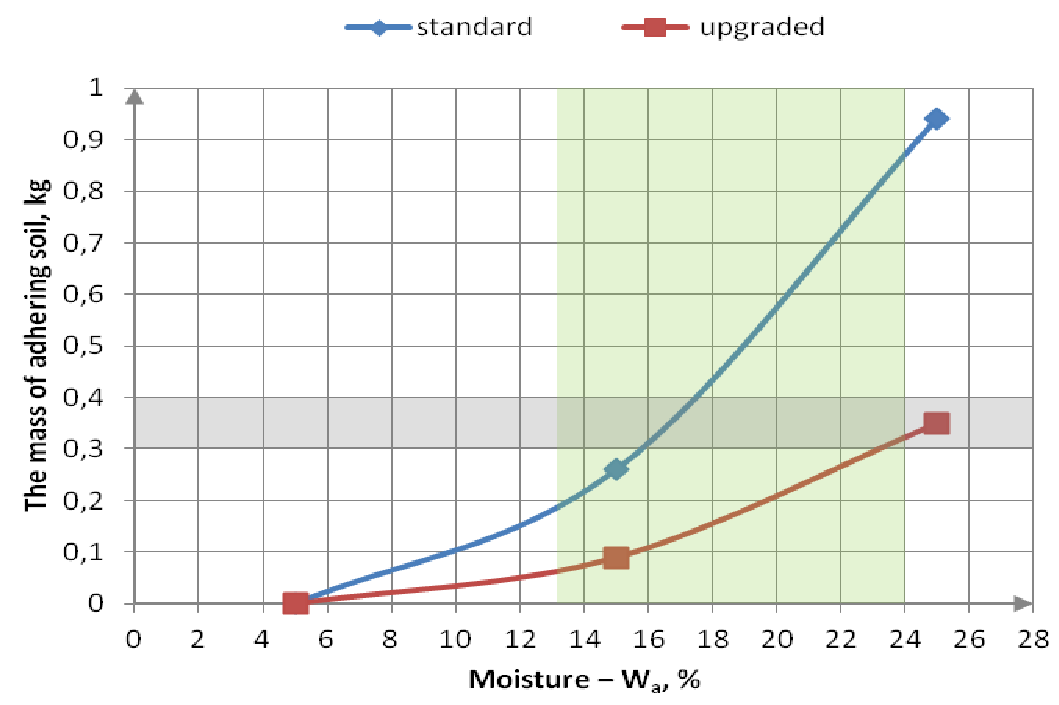

Fig. 5. Dependence of soil mass adhering to disks on its moisture

As it can be seen from Figure 5, with the physical ripeness of the soil $W_{a}=13-24 \%$, the adhesion of the soil to the standard steel double-disc coulter continues to increase rapidly over $0.4 \mathrm{~kg}$, while on the modernized disk during the tests it did not stick more than $0.35 \mathrm{~kg}$, which is 2.9 times less than standard steel under the same operating conditions. That is, with an absolute soil moisture of more than $17 \%$, the soil continues to adhere more and more intensively to the standard coulter, which increases the friction coefficient and traction resistance, disrupting its performance and sowing rates, while the modernized coulter with UHMWPE pad is at the same level as the best working standard coulter for high-quality tillage $-W_{a}=15-18 \%$.

In a multivariate experiment based on the results of an experiment in the soil channel, it was found that the traction resistance $R_{c m}$ of modernized wide row coulters is $40-115 \mathrm{H}$, which is 1.31.5 times lower than that of standard $R_{c s}$ ceteris paribus. As a result, mathematical models of optimization criteria $Y_{i}$ (traction resistance $R_{c i}, \mathrm{H}$ ) for wide-row coulters were constructed depending on the factors adopted. In a decoded form, the regression equations for the optimization criteria under consideration are as follows:

$$
\begin{gathered}
R_{c s}=177.74-145.61 v_{c}+1139.93 h+1 W_{a}+32.38 v_{c}^{2}+0.03 W_{a}^{2}, \\
R_{c m}=126.96-104.01 v_{c}+814.24 h+0.72 W_{a}+21.13 v_{c}^{2}+0.02 W_{a}^{2} .
\end{gathered}
$$

As it can be seen from the results obtained, UHMWPE material can be used to modernize tillage equipment and, in particular, double-disc coulters of grain seeders. It possesses not only hydrophobic properties, but also surpasses steel and fluoroplast- 4 in terms of wear resistance and has a lower friction coefficient. And due to the lower density of polyethylene $2.2-2.6$ times $\left(0.92-0.96 \mathrm{~g} \cdot \mathrm{cm}^{-3}\right)$ than that of fluoroplastic, the weight of the structure made of it is less.

The obtained indices of fluoroplastic strength in comparison with UHMWPE are confirmed by studies [5]. According to these data, its relative wear resistance is 2.6 times higher than that of metal samples from St3, and 6.7 times higher than that of fluoroplastic ceteris paribus. And other authors [7] used UHMWPE in zones of local wear and zones of increased friction of the working body for layerby-layer tillage, which ensured a decrease in traction resistance by $18.3 \%$ and an improvement in the quality of fracture by $6.8-10.4 \%$. 


\section{Conclusions}

1. For modernization of tillage equipment, the polymeric material must possess not only hydrophobic properties, but also be wear-resistant for work on soils of different humidity.

2. Most often, fluoroplastic and polyethylene are used to modernize double-disc coulters while counteracting soil adhesion. We suggest paying attention to such a material as UHMWPE, which, in addition to hydrophobic properties comparable with fluoroplastic, has increased wear resistance up to 6.7-18.0 times compared with it and is not inferior to steel.

3. Due to the very low adhesion to any material, UHMWPE is difficult to adhere and must be mechanically fixed to work surfaces, for example, rivets or clamps. We recommend about 2225 pcs mounted around the circumference of the disk.

4. The obtained experimental data confirm the possibility of using UHMWPE for modernization of double-disc coulters. Its stickiness to soil is lower by 2.9 times, traction resistance is lower by 1.5 times in soils with moisture up to $W_{a}=24-30 \%$ than in steel.

\section{References}

[1] Апажев А.К., Шекихачев Ю.А., Хажметов Л.М. Модернизация зерновой сеялки для работы в условиях повышенной влажности почв (Modernization of a grain seeder for work in conditions of increased soil moisture) Bulletin of the Lower Volga Agricultural University: Science and higher professional education. 2016. No. 3 (43). pp. 238-245. (In Russian).

[2] T.P. Fyfield, P.J. Gregory, T. Woodhead, E.M. Pasuquin Effects of tillage, seeding method and time of sowing on the establishment of mungbean in drying, previously puddled soil. Soil and Tillage Research. Volume 18, Issue 4, December 1990, pp. 333-346 DOI: 10.1016/01671987(90)90118-W

[3] Нотов Р.А., Лебедев А.Т., Искендеров Р.Р. Совершенствование дисковых сошников зерновых сеялок для работы в условиях переменной влажности почвы (Improving disk openers of grain seeders for working in conditions of variable soil moisture). Innovations in the agricultural sector: problems and prospects. - 2019 .- No. 4 (24). - pp. 64-71. (In Russian).

[4] Jin Tong, Ballel. Z. Moayad, Yun-hai Ma, Ji-yu Sun, Dong-hui Chen, Hong-lei Jia, Lu-quan Ren Effects of Biomimetic Surface Designs on Furrow Opener Performance. Journal of Bionic Engineering. Volume 6, Issue 3, September 2009, pp. 280-289 DOI: 10.1016/S16726529(08)60128-6

[5] Alessandra de A. Lucas, José D. Ambrósio, Harumi Otaguro, Lidiane C. Costa, José A.M. Agnelli Abrasive wear of HDPE/UHMWPE blends. Wear, Volume 270, Issues 9-10, 4 April 2011, pp. 576-5834 April 2011, pp. 576-583. DOI: 10.1016/j.wear.2011.01.011

[6] Качалина А.В., Калугина Е.В., Коврига В.В. К оценке износостойкости трубных марок полиэтилена (To the assessment of wear resistance of pipe grades of polyethylene). Polymer pipes. 2007. No. 1 (15). pp. 42-43. (In Russian).

[7] Пархоменко Г.Г., Божко И.В., Громаков А.В., Пахомов В.И. Использование пластика в конструкциях почвообрабатывающих рабочих органов (The use of plastic in the design of tillage working bodies). Tractors and agricultural machinery. 2017. No. 8. pp. 8-15. (In Russian).

[8] Soo-JinPark, Min-KangSeo Chapter 6 - Element and Processing. Interface Science and Technology. Volume 18. 2011. pp. 431-499. DOI: 10.1016/B978-0-12-375049-5.00006-2

[9] Перепелкина С.Ю., Коваленко П.П., Печенко Р.В., Нуждин К.А. Методика исследования трибологических характеристик материалов на машине трения (Methodology for studying the tribological characteristics of materials on a friction machine). University News. Instrument making. 2016.V. 59, No. 8. pp. 636-640. (In Russian).

[10]Патент 190896 Российская Федерация, МПК А 01 C 7/20. Двухдисковый сошник. А.Т. Лебедев, В.В. Очинский, Н.А. Марьин, А.К. Апажев, Р.А. Нотов. (Patent No 190896 Russian Federation, A 01 C 7/20. Double-disc coulter). Applicant and the patent owner Stavropol State Agrarian University. Apl. No 2019110459 it is declared 08.04.2019. It is published 16.07.2015. Bulletin № 20. (In Russian). 